\title{
A Contrastive Analysis of Compound Nouns in German and Albanian Languages
}

\author{
Brunilda Vërçani
}

\section{Abstract}

Language is an important mean of communication and it is constantly changing. During the language change a lot of words become out of use and many other new words become part of lexicon. The lexicon of the language is constantly enlarging and one important way to enlarge a language is by word formation. In German and Albanian Languages word formation is defined as a process of forming new words. In both, German and Albanian Languages an important contribution in word formation is given by compounding. In German Language compound words make up 2/3 of lexical language. The dominant part of compound words is the formation of compound nouns. German Language has got a lot of compound nouns so it has the ability to create new compounds between the connection of nouns or the connection of a noun with the other parts of discourse. In most cases the compounds of German Language find their equivalent in Albanian Language in simple words or phrases. In both languages a compound noun consists of two or more (lexical parts) components; they can have subordinate and coordinate relations. The majority of compounds is done by coordinate relations (determinate compositions). The composition components have a strict word order. If the word order changes in German Language, the meaning of composition will change, it will take a new meaning. (Of course there are exceptions in a few cases). If the word order changes in Albanian Language, the word becomes meaningless. In Albanian language the components of a compound noun are connected without fugues. Compound nouns with connecting vowels (o / a) are very few, while in German linking elements (fugues : e-, -s-, -es-, -n-, -en-, -er-, -ens-, -o-, ) are typical.

Keywords: word formation, composition, compound nouns

\section{Introduction}

Language is an important mean of communication and it is always changing. New and continuous developments in science, economy, politics etc introduce new objects and concepts that should be named (Engel,2004, p.278). The process of creating new words is called word formation which has always been part of different studies. There are a lot of definitions for the term of "word formation". Here are some of them: 
Word formation is a language discipline which describes the way that words are built and how new words are created (Metzler, 2016, p. 771).

Word formation is a universal linguistic principle according to which new words are formed based on existing elements (Hentschel,2010,p.390).

Word formation studies and describes the process and rules of forming new words based on existing language forms (Bussmann ,2002).

In grammar books on the Albanian Language word formation is defined as a process of forming new words. The composition gives a big contribution in forming new words, typically in forming new nouns. In German Language compound words make up $2 / 3$ of the vocabulary (Duden, 1998, p. 409). In Albanian Language the most productive way of forming new words is composition (Gramatika e Gjuhës Shqipe I,2002).

Composition is a process of word formation that creates new words. These words have two or more motivational themes (Gramatika e Gjuhës Shqipe I, 2002). There are similar definitions in German Language as well.

Composition is the joining of two or more morphemes or words in only one word (Metzler, 2016,p.351).

Composition is the union of a construct of morphemes the components of which can also appear as free morphemes (Fleischer,1976,p.53).

Compositions are created if the elements of discourse that serve as separate words, are combined into a single word. (Henzen,1957,p.36)

By composites we mean a way of word formation, where two elements are related to each other. (Hentschel, 2010 ,p.151)

Since the composition gives the main contribution in the formation of names in both languages, we will focus in more details on the names composed in Albanian and German.

\section{Composition in Albanian Language}

Compound nouns are created by two or more motivating themes one of which (the supporting theme which is usually the second) grammatically forms the whole composition. The other theme (or other themes when there is more than one) does not retain its grammatical meanings, for example: bregdet (Meeresküste / seaside), botëkuptim (Weltanschauung / worldview), vendbanim (Wohnort / residence) etc (Gramatika e Gjuhës Shqipe I, 2002, p.70).

Parts of compositions may have coordinate or subordinate relations between them. According to this criterion there are copulative compounds whose parts are related by coordination and determinative compositions where one of the parts defines the 
other. Most compound nouns are those with subordinating relations, determinative compositions. (Gramatika e Gjuhës Shqipe I, 2002, p.71).

In Albanian Language the connection of words is done without linking tools. There are a few compound nouns which are linked with a vowel (Kostallari 1972,p.84): gushtovjeshtë (August oder Herbst /august or autumn), peshkaqen (Hai /shark) etc.

There are some kinds of compound nouns. The following types appear in the Grammar of the Albanian Academy of Sciences (Gramatika e Gjuhës Shqipe I, 2002):

Compound words formed by two nouns:

Noun + Noun derived from the verb (doer of the action) :

gjakpirës (Blutsauger / bloodsucker), bukëpjekës (Bäcker / baker), gjellëbërës (Koch /cook), rrobaqepës (Schneider / tailor), akulloreshitës (Eisverkäufer / ice-cream vendor)

Noun + Noun derived from the verb ( the action):

dëmshpërblim (Schadenersatz /indemnity) hakmarrje (Rachen / revenge), mikpritje (Gastfreundschaft / hospitality), armpushim (Waffenstillstand / ceasefire), fjalëformim (Wortbildung / wordformation)

Noun + (any) Noun:

bregdet (Meeresküste / seaside),jetëgjatësi (Langlebigkeit /longevity), mesditë (Mittag / midday), zemërgjerësi (Großzügigkeit / generosity)

Adverb + Noun

bashkëpunim (Zusammenarbeit / cooperation), keqkuptim ( Missverständnis / misunderstanding), mirëmbajtje (Instandhaltung/maintenance)

Pronoun + Noun

vetëshërbim (Selbstbedienung / self-service)

Numeral+ Noun dyluftim (Zweikampf / duel) trekëndësh (Dreieck / triangle)

Noun +Adjective

gushëkuq (Gimpel / bullfinch), lulëkuqe (Mohn / poppy)

Verb + Noun

vëmendje (Aufmerksamkeit / attention)

Noun+ Verb

ujëvarë (Wasserfall / waterfall)

Inside the word formation there is needed to take into consideration the combination of words: composition + apposition. There are a few nouns in the group of 
composition + apposition: dorëheqje (Rücktritt / resignation), frymëmarrje (Atmung / breathing), kryengritje (Aufstand/uprising), zëvendës (Vize /vice) etc.

\section{Composition in German Language}

The term composition is typical in German Language because composition is very common (Engel, 2004, p.283). The predominant part of the compositions are nouns, which form the most voluminous class of words and are quickly added to the number (Engel, 2004, p.287).

Both in Albanian and German Languages compound nouns are created by two lexical parts, one part takes the main accent and the other part takes the secondary accent. These components are: the determinative word and the basic word. Grammatical function and semantic category of composition are usually defined from the basic word (Duden, 1998, p.480).

Eisenberg has seen composition parts as two forms that are related with each other. He named the first part as the head of composition and the second part as the nucleus of it (Eisenberg 2013, 217). According to him the head defines grammatical category, whereas the nucleus defines semantics. As in Albanian Language both parts of composition may have coordinate and subordinate relation. Composition in coordinate relation is limited in its production. These are mostly found in professional language, for example in chemistry, journalism, fashion etc (Duden,1998, p.481).

The parts of the copulative compositions come from the same world class and they have coordinate relations with each other. It looks like they are connected with the conjunction und (alb.dhe/and) (Hemdbluse - alb.bluzë këmishë) Bluse und Hemd bluzë dhe këmishë / blouse and shirt)(Duden,1998, p.481). The word order can change for example :Hosenrock(alb. Fundpantallona/ skirtpants) or Rockhose (skirt pants) and the second part can substitute the whole composition: Seidenkleid(alb. fustan mëndafshi / silk dress) -Kleid(alb. fustan / dress).

As in Albanian Language, the majority part of composition is a determinative composition. The order of the parts of these compounds is fixed and clearly defines the meaning of the composite. Changing their order leads to a change of meaning Reisebus(alb. autobus udhëtimi) / coach Busreise(alb. udhëtim me autobus) / bus trip (Duden,1998, p.482). There are some exceptions too.

Within the determinative compounds one recognizes the subgroup of possessive compounds, where the first term semantically specifies the second. The composition refers to a prominent characteristic: Langbein - alb. Këmbëgjatë / long leg.

In contrast to copulative compounds which almost always consist of only two lexemes, in determinative composites they can also consist of three, four or more parts.

In these cases the determinative part or the basic part may be a compound noun. (Tiefdruckgebiet (alb. zonë e presionit të ulët)/low pressure area, Frischwasserbehälter 
(alb. enë/mbajtëse për ujë të freskët) / fresh water container. This combination can be found even in Albanian Language: vajgursjellës (oilman), zëvendësministër (vice minister) etc. For this kind of composition there are some types of creations:

Left branching (Linksverzweigung: Armbanduhr (alb. Orë dore) / wrist watch, Bergbauwissenschaftsstudium (alb. Studime në shkencat e minierave)/mining sciences studies)

Right branching (Rechtsverzweigung: Reiseschreibmaschine (alb. Makinë shkrimi për udhëtime)/travel typewriter, Gartengrundstück/plot)

Left - right - branching (Links- Rechts- Verzweigung: Druckluftbremszylinder (alb. Cilindri i frenave të ajrit)/ air brake cylinder, Kleinkinderspielplatz (alb. kënd lojrash për fëmijët e vegjël)/toddler playground)

It is typical for German Language to create long compositions with a lot of parts. These words are mostly found (in addition to everyday language) in science, technology, administration etc.

Haustürschlüssel (alb. çelësi i derës së shtëpisë/front door key)

Geburtstagsgeschenk (alb. dhurata e ditëlindjes / birthday present) Gemeindegrundsteuerveranlagung (alb. vlerësimi i taksës së pronës komunale / local property tax assessment)

Verkehrsinfrastrukturfinanzierungsgesellschaft (alb. kompania e financimit të infrastrukturës së transportit / transport infrastructure finance company)

Windschutzscheibe (alb. xhami i përparmë i makinës / windshield)

Abblaseventilstellzylinder ( alb. cilindër i aktivizuesit të valvulës së shkarkimit / exhaust valve actuator cylinder)

A simple case is made up by two parts. The second part is a noun and the first part may be a noun, adjective, verb etc (Eisenberg, 2013, p.217). Based on this - , the types of composite formation are:

Noun + Noun

Weizenbrot (alb. bukë gruri/ wheat bread), Schulsachen (alb. sende shkollore / school supplies), Angriffspunkt ( alb. pikë sulmi / attackpoint), Berggipfel (alb.majë mali / mountain peak), Fehlerzahl (alb.numri i gabimeve / number of errors), Zahnpflege(alb. perkujdesje dentare / dental care), Käsebrot (alb. bukë me djathë/ cheese bread)

This kind of combination makes up 4/5 of all composition nouns. Groups of words with a determinant correspond to these composites.

Adjective / Participle + Noun

This kind of combination makes up a few word formation. 
Sauerkirsche (alb.vishnje/ sour cherry), Kleinkind (alb. fëmijë i vogël /toddler), Gebrauchtwagen (alb. makinë e përdorur/used car), Hartarbeit (alb. punë e vështirë / hard work), Flachdach (alb. çati e sheshtë / flat roof)

Numeral + Noun

This is a kind of composition that is iscreasing nowadays.

Zweikampf (alb. dyluftim / duel), Vierbeiner( alb. katërkëmbësh / four legged friend), Dreiachser (alb. (mjet)me tri akse / three axle), Dreirad (alb.(mjet) me tre rrota (triçikël) /tricycle) , Achtzylinder (alb. me tetë cilindra / eight - cylinder)

Verb + Noun

Esstisch (alb. tavolinë ngrënie/dining table), Waschmaschine (alb. lavatriçe/washing machine) , Gehverband (alb. allçi (në këmbë)/walking bandage), Hörgerät (alb. aparat dëgjimi /hearing aid), Leselampe (alb. abazhur për lexim / reading lamp)

Adverb / Preposition + Noun

Hintertür (alb. dera e pasme /back door), Sofortprogramm (alb. program $i$ menjëhershëm / immediate program), Zusammenarbeit (alb. bashkëpunim / cooperation)

In most cases the connection of composition is done without linking elements (fugues). In other specific cases the connection is done with linking elements. There is often a space (fugue) between two composition parts (Hochzeit-s-torte - alb. torta e dasmës/ wedding cake, Therm-o-meter - alb. termometër/thermometer). In these spaces are often inserted different sounds, which are defined as connecting elements.They don't have a meaning but they serve to facilitate the word articulation (Duden,1998,498). While according to Fuhrhop these connecting elements are the most important morphological tool for structuring the composite.(Fuhrhop, 2000). The connecting elements in German Language are: $e-,-s-,-e s-,-n-,-e n-,-e r-,-e n s-,-o-$.

Rettungswagen (alb. ambulanca / ambulance), Krankenhaus (alb. spital / hospital), Rinderzucht (alb. rritja e gjedhëve/ cattle breeding), Gästebuch (alb. libri i vizitorëve / guest book)

\section{Similarities and differences}

Compositions in the Albanian language have a single accent, while in German each part has its own accent.

In German the composition components have a strict word order. If the word order changes in German Language, the meaning of composition will change, it will take a new meaning. If the word order changes in Albanian Language, the word is meaningless.

In both languages the constituent parts of the composition have a coordinating or subordinating relationship between them. 
In Albanian and German Languages the largest number of compound nouns are determinative compounds. One of their parts may even be a compound noun.

German language is known for the ease of forming composites and for the creation of long compositions. Long compounds are hard to find in Albanian Language. There are difficulties in translating a word from German into Albanian Language because words have different forms. In order to find an equivalent, it is needed to make a long paraphrasing.

German and Albanian Languages have in part different techniques or possibilities of expressing and naming things. This fact is seen in the process of forming compositions. In German Language there are a lot of cases when it is used a composition, while in Albanian Language it is used a simple word or phrase (German : Klassenzimmer - Albanian: klasë / classroom).

In German Language, it is typical that parts of words are linked with fugues, whereas in Albanian Language this procedure can happen very rarely.

\section{Conclusions}

An important contribution in word formation in the German and Albanian Languages is given by composition. The dominant part of compound words is the formation of compound nouns. Albanian and German sometimes have different techniques or ways of naming or expressing a situation,which is then also reflected in the use of compound words. In German it is simply easier to spontaneously form new compound words. In both languages, most noun words are two - part , but there are also multipart noun compounds, especially typical for the German language, which is known for its overlong compound words.

In most cases the compositions of German Language find their equivalent in Albanian Language in simple words or phrases.

In German Language, it is typical that parts of words are linked with fugues, whereas in Albanian Language this procedure can happen very rarely.

\section{References}

[1] Akademia e shkencave (2002) Gramatika e gjuhës shqipe I, Tiranë, 2002

[2] Bußmann, H. (2002) Lexikon der Sprachwissenschaft. Stuttgart.

[3] Cipo, K.(1972) Kompozitat determinative, në: Studime mbi leksikun dhe mbi formimin e fjalëve në gjuhën shqipe I, Tiranë

[4] Cipo K. (1972) Rreth disa kompozitave, në: Studime mbi leksikun dhe mbi formimin e fjalëve në gjuhën shqipe I, Tiranë

[5] Demiraj SH. (1961) Morfologjia e gjuhës së sotme shqipe, II, Tiranë

[6] Duden (1998) Die Grammatik, Band 4, Mannheim 
[7] Eisenberg P. (2013) Grundriss der deutschen Grammatik, das Wort, Stuttgart

[8] Engel U. (2004) Deutsche Grammatik, Heidelberg

[9] Fleischer W. (1976) Wortbildung der deutschen Gegenwartssprache, Leipzig

[10] Fuhrhop N. (2000) Zeigen Fugenelemente die Morphologisierung von Komposita an? In: Thieroff (Hg. 2000), 201-213.

[11] Hentschel E. (2010) Deutsche Grammatik, Berlin

[12] Henzen W. (1957) Deutsche Wortbildung, Tübingen

[13] Hysa E. (1985) Dukuri e prirje të formimit të fjalëve në shqipen e sotme letrare, në: Gjuha

Jonë1/1985

[14] Kostallari A. (1972) Mbi disa veçori të fjalëve të përbëra në gjuhën shqipe, në: Studime mbi leksikun

dhe mbi formimin e fjalëve në gjuhën shqipe I, Tiranë

[15] Metzler Lexikon Sprache (2016) Stuttgart,

[16] Thomai J. (2011) Leksikologjia e gjuhës shqipe, Tiranë

[17] https://slideplayer.org/slide/4094002/ 